\title{
MENGENAL VALUASI STARTUP DAN \\ ISTILAH UNICORN
}

\section{SANDI JUNIANSAH \\ 165100016}

Fakultas Komputer

sandijuniansah.student@umitra.ac.id

\begin{abstract}
Untuk menentukan nilai valuasi dari sebuah startup sangat sulit sebenarnya. Dari sisi founder pasti merasa yang mereka kerjakan itu harganya tinggi sekali. Sementara dari investor, kita melihat kalau kita masuk di valuasi sekarang, di valuasi berapa kita bisa exit. Jadi valuasi pada saat investasi itu ditentukan nilai tengah dari ekspektasi investor dan founder. tartup sebenarnya juga punya hak untuk menentukan nilainya sendiri. Hal yang mungkin ditunjukkan untuk menyanggah nilai valuasi yang dinilai terlalu rendah bisa menggunakan perbandingan dan proyeksi keuangan. Perbandingan biasanya dilakukan dengan cara menilai kapabilitas dan laju perkembangan startup yang bermain di sektor sama di pangsa pasar yang sama. Bagaimana jangkauan produk, traksi pengguna hingga varian produk yang ada di dalamnya akan menjadi bagian penting dalam komparasi tersebut.
\end{abstract}

Kata Kunci : Mengenal Valuasi Startup Dan Istilah Unicorn

\section{A. PENDAHULUAN}

Materi Kuliah Membahas Tentang Pengantar Struktur Data membahas mengenai i cloud system ...dst tambahkan gambar untuk memperkuat penjelasan ( Gunakan Minimal 400 kata )

JAWAB:

\section{Mengenal Valuasi Startup Dan Istilah Unicorn}

Semenjak makin banyak startup Indonesia yang berhasil mendapat pendanaan dengan nilai yang sangat fantastis, istilah valuasi startup kencang didiskusikan oleh masyarakat. Lalu sebenarnya apa itu valuasi dan bagaimana cara melakukan kalkukasi untuk menentukan valuasi sebuah startup? 
Singkatnya valuasi merupakan nilai dari suatu startup. Karena umumnya startup itu masih tergolong semienterprise, biasanya nilai valuasinya ditentukan berdasarkan peretujuan antara founder dengan investor. Tidak ada perhitungan yang saklek untuk menentukan valuasi.

Umumnya investor memiliki benchmark internal dan prosedur penghitungan valuasi, mulai dilihat dari kapabilitas founder/co-founder, produk yang dipasarkan, traksi pengguna hingga potensi produk tersebut ke depan.

Di sisi lain valuasi juga memerlukan pembuktian. Ketika ada yang bertanya "berapa nilai perusahaan tertentu?", jawabannya harus merefleksikan komponen apa saja yang mampu dijadikan daftar dalam penentuan nilai tersebut. Menariknya startup di Indonesia sendiri memiliki proses yang unik, jadi antara satu dengan yang lainnya kadang memiliki pendekatan yang berbeda dalam melakukan perhitungan valuasi. Jumlah modal yang ditanamkan, jumlah investor, kekuatan produk dan kredibilitas founder terlibat besar di dalamnya.

Perhitungan valuasi paling mudah bisa dicontohkan dengan perhitungan modal awal dan suntikan dana investor. Misal sebuah startup memiliki nilai awal $\mathrm{Rp} 10$ miliar, kemudian sebuah venture capital menambahkan pendanaan $\mathrm{Rp} 10$ miliar, berarti valuasi startup menjadi Rp 20 miliar dengan kepemilikan saham 50\% milik venture capital tersebut. Biasanya perhitungan ini akan berjalan jika startup memang sudah mapan berdiri dan apa yang diproduksi sudah jelas.

Namun pada praktiknya tak semudah itu untuk menghitung capaian valuasi. Managing Partner East Ventures Willson Cuaca mengatakan:

"Untuk menentukan nilai valuasi dari sebuah startup sangat sulit sebenarnya. Dari sisi founder pasti merasa yang mereka kerjakan itu harganya tinggi sekali. Sementara dari investor, kita melihat kalau kita masuk di valuasi sekarang, di valuasi berapa kita bisa exit. Jadi valuasi pada saat investasi itu ditentukan nilai tengah dari ekspektasi investor dan founder."

\section{B. PEMBAHASAN / STUDI KASUS}

Anda Boleh menjelaskan ( Baca: Hal yang akan anda paparkan pada bagian content ini ) ; ex:Materi $\mathrm{Ke} 1$ membahas mengenai i cloud system ...dst tambahkan gambar untuk memperkuat

penjelasan ( Gunakan Minimal 600 kata ) \& ID Secuity \& Reference dibawah Tidak Boleh Dirubah

\section{JAWAB:}

Untuk menentukan nilai valuasi sendiri, satu startup dengan startup lainnya memang memiliki pendekatan yang berbeda-beda. Ada beberapa hal yang mungkin mempengaruhi nilai valuasi 
startup. Pertama adalah nilai yang ditentukan oleh pasar (umumnya diwakili oleh investor). Misalnya jika investor mengatakan bahwa startup X bernilai \$5 juta, maka itulah nilai yang layak. Namun kadang founder merasa nilainya harus lebih tinggi, misalnya ternyata ada aset atau kekuatan dari talenta bisnis yang dihitung bernilai lebih, namun jika startup tidak bisa mengumpulkan uang dari aset itu senilai penilaian valuasi tadi, maka startup memang harus menerima penilaian pasar.

Startup sebenarnya juga punya hak untuk menentukan nilainya sendiri. Hal yang mungkin ditunjukkan untuk menyanggah nilai valuasi yang dinilai terlalu rendah bisa menggunakan perbandingan dan proyeksi keuangan. Perbandingan biasanya dilakukan dengan cara menilai kapabilitas dan laju perkembangan startup yang bermain di sektor sama di pangsa pasar yang sama. Bagaimana jangkauan produk, traksi pengguna hingga varian produk yang ada di dalamnya akan menjadi bagian penting dalam komparasi tersebut.

Yang kedua adalah proyeksi keuangan. Tak mudah memang melakukan memastikan angkanya, namun tren dan traksi pengguna yang ada dari waktu sebelumnya seharusnya dapat dijadikan acuan, terlebih untuk produk digital, maka proyeksi tersebut akan lebih mudah dianalisis juga didasarkan dengan upaya pemasaran yang akan dibubuhkan.

Cara yang paling mudah untuk menunjukkan valuasi tak lain adalah dengan menunjukkan profit bisnis. Menunjukkan kepada semua orang bahwa bisnis yang dijalankan mampu memberikan keuntungan yang fantastis. Ini pun menjadi tantangan untuk startup, karena rata-rata di fase awal fokus bisnis memang akan condong kepada akuisisi pengguna dan perluasan pangsa pasar. Untuk itu biasanya akan muncul pertanyaan-pertanyaan yang mengacu pada berapa tahun yang diperlukan sehingga bisnis bisa menguntungkan? Membandingkan berapa banyak perusahaan sejenis dan perbandingannya dalam mencapai profit?

Pada dasarnya penentuan valuasi startup memang menjadi sebuah proses seni. Seperti pada sebuah lukisan, penilaian kadang didasarkan poin-poin yang sulit dikalkulasikan secara matematis.

\author{
C. ID SECURITY \\ QWTD4452377-ASP-5244107
}




\section{KESIMPULAN}

Kesimpulan dari materi ini adalah ....( minimal 150 kata $)$

JAWAB:

dibutuhkan. Pengendalian

Internal tersebut bertujuan untuk mewujudkan 20

efektivitas dan efisiensi operasi, keandalan laporan keuangan, kepatuhan terhadap hukum dan peraturan.

\section{E. DISKUSI}

Saya bersama teman saya bernama Rudi mendiskusikan tentang contoh ini dengan sangat baik Hasil diskusi dari materi ini adalah ....( minimal 150 kata )

JAWAB:

Setelah mengenal tentang valuasi, umumnya orang akan berdiskusi tentang unicorn, sebuah "gelar" yang diberikan kepada startup yang memiliki valuasi lebih dari \$1 miliar. Di Indonesia sendiri memang belum banyak startup unicorn. Salah satu yang sering digadang-gadang adalah Tokopedia, Traveloka, dan Go-Jek. Pada putaran pendanaan terakhir, Go-Jek berhasil membekukan valuasi $\$ 1,3$ miliar.

Lalu muncul pertanyaan, mengapa valuasi Go-Jek bisa mencapai angka tersebut? Apa saja yang mempengaruhinya? Untuk menjelaskan tentang hal tersebut, kami mencoba berdiskusi dengan CEO MDI Ventures Nicko Widjaja.

Nicko banyak menjelaskan tentang dinamika bisnis di pangsa pasar on-demand dan persaingan di sektor itu sendiri. Spesifik tentang pembahasan Go-Jek dan gelar unicorn-nya, Nicko juga menyampaikan bagaimana pandangan pasar dari kaca mata investor sehingga memberikan kepercayaan meningkatkan valuasi Go-Jek itu sendiri.

"Dengan Grab memperoleh pendanaan Seri F $\$ 600$ juta (di waktu yang hampir sama dengan pendanaan Go-Jek), Go-Jek bersaing di pasar (ondemand lokal) yang belum jelas siapa pemimpin pasarnya. Saat ini penilaian didorong oleh market value. Didi memiliki valuasi $\$ 36$ miliar, Uber $\$ 70$ miliar, dan terakhir Uber Cina diakuisisi oleh Didi."

Ia melanjutkan bahwa pada saat yang sama semua venture capital pendukung berinvestasi untuk mencari "killer" untuk pangsa pasar di wilayah tersebut. Nilai unik Go-Jek sebagai masa depan bisnisnya adalah revolusi layanan pembayaran 
dengan Go-Pay. Mereka tidak mematokkan diri sebagai pemain di sektor transportasi, tapi sebagai sebuah platform yang memberikan berbagai jasa layanan untuk kebutuhan sehari-hari melalui sistem ondemand.

"Menjadi investor di pasar berkembang di Asia Tenggara, berarti bahwa kita berinvestasi dalam ekosistem dan infrastruktur. Go-Jek telah memainkan peran penting dalam membangun ekosistem dan infrastruktur mereka untuk [membudayakan] masyarakat melek digital," ujar Nicko.

\section{F. REFERENCE}

[1] O. M. Febriani and A. S. Putra, "Sistem Informasi Monitoring Inventori Barang Pada Balai Riset Standardisasi Industri Bandar Lampung," J. Inform., vol. 13, no. 1, pp. 90-98, 2014.

[2] A. S. Putra, "Paperplain: Execution Fundamental Create Application With Borland Delphi 7.0 University Of Mitra Indonesia," 2018.

[3] A. S. Putra, "2018 Artikel 
Struktur Data, Audit Dan Jaringan Komputer," 2018.

[4] A. S. Putra, "ALIAS MANAGER USED IN DATABASE DESKTOP STUDI CASE DB DEMOS."

[5] A. S. Putra, "COMPREHENSIVE SET OF PROFESSIONAL FOR DISTRIBUTE COMPUTING."

[6] A. S. Putra, "DATA ORIENTED RECOGNITION IN BORLAND DELPHI 7.0."

[7] A. S. Putra, "EMBARCADERO DELPHI XE 2 IN GPUPOWERED FIREMONKEY APPLICATION."

[8] A. S. Putra, "HAK ATAS KEKAYAAN INTELEKTUAL DALAM DUNIA TEKNOLOGY BERBASIS REVOLUSI INDUSTRI 4.0.”

[9] A. S. Putra, "IMPLEMENTASI PERATURAN

PERUNDANGAN UU. NO 31 TAHUN 2000 TENTANG DESAIN INDUSTRI BERBASIS INFORMATION TECHNOLOGY."

[10] A. S. Putra, "IMPLEMENTATION OF PARADOX DBASE."

A. S. Putra, "IMPLEMENTATION OF TRADE SECRET CASE STUDY SAMSUNG MOBILE PHONE."

[12] A. S. Putra, "IMPLEMENTATION PATENT FOR APPLICATION WEB BASED CASE STUDI WWW. PUBLIKLAMPUNG. COM."
A.
S.
Putra,

SYSTEM FIRST TO INVENT IN DIGITALLY INDUSTRY."

[14] A. S. Putra, "MANUAL REPORT \& INTEGRATED DEVELOPMENT

ENVIRONMENT BORLAND DELPHI 7.0."

[15] A. S. Putra, "PATENT AS RELEVAN SUPPORT RESEARCH."

[16] A. S. Putra, "PATENT FOR RESEARCH STUDY CASE OF APPLE. Inc."

[17] A. S. Putra, "PATENT PROTECTION FOR APPLICATION INVENT."

[18] A. S. Putra, "QUICK REPORT IN PROPERTY PROGRAMMING."

[19] A. S. Putra, "REVIEW CIRCUIT LAYOUT COMPONENT

REQUIREMENT ON ASUS NOTEBOOK."

[20] A. S. Putra, "REVIEW TRADEMARK PATENT FOR INDUSTRIAL TECHNOLOGY BASED 4.0."

[21] A. S. Putra, "TOOLBAR COMPONENT PALLETTE IN OBJECT ORIENTED PROGRAMMING."

[22] A. S. Putra, "WORKING DIRECTORY SET FOR PARADOX 7."

[23] A. S. Putra, "ZQUERY CONNECTION

IMPLEMENTED

PROGRAMMING STUDI CASE PT. BANK BCA Tbk."

[24] A. S. Putra, D. R. Aryanti, and I. Hartati, "Metode SAW (Simple Additive Weighting) sebagai Sistem Pendukung Keputusan Guru Berprestasi 
(Studi Kasus: SMK Global Surya)," in Prosiding Seminar Nasional Darmajaya, 2018, vol. 1, no. 1, pp. 85-97.

[25] A. S. Putra and O. M. Febriani, "Knowledge Management Online Application in PDAM Lampung Province," in Prosiding International conference on Information Technology and Business (ICITB), 2018, pp. 181-187.

[26] A. S. Putra, O. M. Febriani, and B. Bachry, "Implementasi Genetic Fuzzy System Untuk Mengidentifikasi Hasil Curian Kendaraan Bermotor Di Polda Lampung," SIMADA (Jurnal Sist. Inf. dan Manaj. Basis Data), vol. 1, no. 1, pp. 21-30, 2018.

[27] A. S. Putra, H. Sukri, and K. Zuhri, "Sistem Monitoring Realtime Jaringan Irigasi Desa (JIDES) Dengan Konsep Jaringan Sensor Nirkabel," IJEIS (Indonesian J. Electron. Instrum. Syst., vol. 8, no. 2, pp. 221-232.

[28] D. P. Sari, O. M. Febriani, and A. S. Putra, "Perancangan Sistem Informasi SDM Berprestasi pada SD Global Surya," in Prosiding Seminar Nasional Darmajaya, 2018, vol. 1, no. 1, pp. 289-294. 